\title{
PEMBERDAYAAN KELOMPOK NELAYAN KEPITING MELALUI PEMAHAMAN AKSES PERMODALAN DAN ANALISA USAHA KEPITING BAKAU
}

\author{
Abu Darda Razak ${ }^{1}$, Misbah Sururi ${ }^{2}$, Hendra Poltak $^{3}$ \\ 1,2,3 Teknologi Penangkapan Ikan, Politeknik Kelautan dan Perikanan Sorong \\ Email: hendra.poltak@polikpsorong.ac.id
}

\begin{abstract}
The potential of mang rove habitat which has higheconomic potential cannot be optimized to improve the welfare of mangrove crab fishermen. Capital factors and lack of understanding in conducting business analysis are problems for fishermen who carry out their business activities to increase their income. The purpose of this community service is to provide an understanding of access to capital and business analysis of mud crab so that fishermen are able to carry out business analysis independently. The solution to the problem is carried out in the coordination stage with the fisheries office, surveys, Forum Group Discussions, implementation of communityservice through lectures u sing media challenges that invite fisheries and banking offices and empathetic team mentoring of locations, and evaluation of activities through interviews. The results of the activity provide an increase in partners' understanding of the process of facilitating banking capital and business feasibility analysis.
\end{abstract}

Keywords: crabfishermen, capital, business analysis

\begin{abstract}
Abstrak. Potensi habitat mangrove yang memiliki potensi ekonomis tinggi belum dapat dioptimalk an untuk meningkatkan kesejahteraan bagi nela yan kepiting bakau. Faktor permodalan dan ketidakpaham an melakukan analisa usaha menjadi permasalahan baginelayan dalam menjalan kan ak tivitas u sahanya menin gkatkan pendapatannya. Tujuan pengabdian masyarakat ini adalah untuk memberikan pemaha man akses permodalan dan analisa usaha kepiting bakau sehingga masyarakat nelayan ma mpu m elakukan a nalisa usaha secara mandiri. Solusi permasalahan mitra dilakukan melalui ta hapan koord ina si den gan pihak dinas perikanan, survey, Forum Group Discussion, pelaksanaan pengabdian mas ya rakat m elalui ceramah menggunakan media daring yang mengundang dinas perikanan dan perbankan dan pendampingan tim secara luring diem pat lokasi, serta evaluasi keberhasilan kegia tan melalui wa wancara. Hasilkegia tan memberikan peningkatan pemahaman mitra terhadap prose s fasilitasi permodalan perbankan dan analisa kelayakan usaha.
\end{abstract}

Kata kunci : nelayan kepiting, permodalan, Analisa usaha

\section{PENDAHULUAN}

Kekayaan ekosistem mangrove di Papua

Barat dengan keanekaragaman biota laut bernilai ekonomis tinggi seperti ikan kakap, kepiting, udang, kerang-kerangan dan biota lainnya menjadi berkah bagi kehidupan manusia, terlebih masyarakat yang hidup di wilayah pesisir (Econusa, 2020). Kerapatan mangrove yang masih terjaga ini jika dapat dimanfaatkan dengan baik tentu akan dapat memenenuhi kebutuhan hidup bahkan lebih dari itu dapat mensejahterakan masyarakat pesisir terutama yang bermata pencaharian nelayan kepiting.

Besarnya potensi ini tentunya memberikan berkah bagi kehidupan masyarakat pesisir yang memang menggantungkan kehidupannya dengan melakukan penangkapan hasil laut. Namun, potensi yang luar biasa tidak dapat dimanfaatkan seluruhnya oleh mereka.
Nelayan sebagai salah sosok kunci suksesnya kampanye sosial jargon "ayo makan ikan" supaya cerdas untuk meningkatkan SDM berkualitas, kehidupan sosial ekonominya masih jauh dari kata sejahtera. Kehidupan masyarakat pesisir masih begitu-begitu saja berkutat dengan masalah ekonomi, ironi nya miskin di laut yang kaya (Anwar and Wahyuni, 2019).

Ironi memang, tapi ini adalah gambaran nyata yang terjadi pada nelayan perikanan kepiting di Kota Sorong. Kondisi seperti ini butuh intervensi yang tepat sasaran untuk menyelesaikan permasalahan mitra. Tahapan intervensi dimulai dengan survey awal bekerja sama dengan penyuluh perikanan Kota Sorong. Hasil survey dikonfirmasi dengan pelaksanaan Focus Group Discussion untuk mendapatkan pemahaman mendalam permasalahan sosial 
(Nyumba et al., 2018), sehingga memudahkan menentukan solusi pemecahan,

Khalayak sasaran (mitra) ditetapkan empat kelompok masyarakat pesisir yang berprofesi sebagai nelayan kepiting bakau dengan jumlah mitra sebanyak 30 orang.

Kelompok tersebut terdiri dari tiga kelompok di wilayah Kota Sorong yaitu kelompok Kelurahan Tampa Garam, Kelompok Rimbapala, dan Kelompok Kladufu. Kelompok di wilayah Kabupaten Sorong adalah kelompok SP3. Mitra pengabdian masyarakat rata-rata berpendidikan Sekolah Menengah Pertama (SMP). Nelayan kepiting bakau dalam melakukan operasi penangkapan menggunakan perahu katinting dan alat tangkap bubu.

Kelompok masyarakat yang mendapatkan materi diharapkan dapat menerapkan materi tersebut dalam pelaksanaan usahanya. Mitra dapat memahami alur proses dan persyaratan dalam upaya memperoleh permodalan melalui perbankan, disamping itu juga dapat menganalisis usaha penangkapan kepiting yang sudah berjalan maupun dalam tahap perencanaan. Pemahaman pengetahuan yang diberikan dapat menjadi bekal untuk mitra dalam meningkatkan kesejahteraannya.
Penelitian dan pengabdian masyarakat terdahulu mendukung kegiatan ini. Penelitian yang dilakukan Makinggung and Winokan (2017) bahwa usaha nelayan berpotensi untuk dikembangkan melalui melalui manajemen usaha oleh perguruan tinggi. Upaya peningkatan pendapatan dan kesejahteraan masyarakat dilakukan dengan pemberdayaan manajemen usaha secara intensif dan terpadu dari pemerintah dan kolaborasi perbankan melalui optimalisasi Kredit Usaha Rakyat (KUR) (Patra and Patra, 2018). Pelatihan dan pendampingan penyusunan proposal pengajuan kredit bank bagi kelompok usaha perikanan di wilayah Kelurahan Rangkap Jaya Baru mampu mengatasi kendala keterbatasan modal (Tristiarto, Kusmana, \& Siswantini, 2017).

\section{METODE PELAKSANAAN}

Kegiatan pengabdian masyarakat bagi mitra disepakati adalah kegiatan pemahaman cara memperoleh fasilitas permodalan melalui perbankan dan analisa kelayakan usaha perikanan kepiting bakau. Pencapaian Tujuan pengabdian masyarakat dilakukan melalui tahapan :

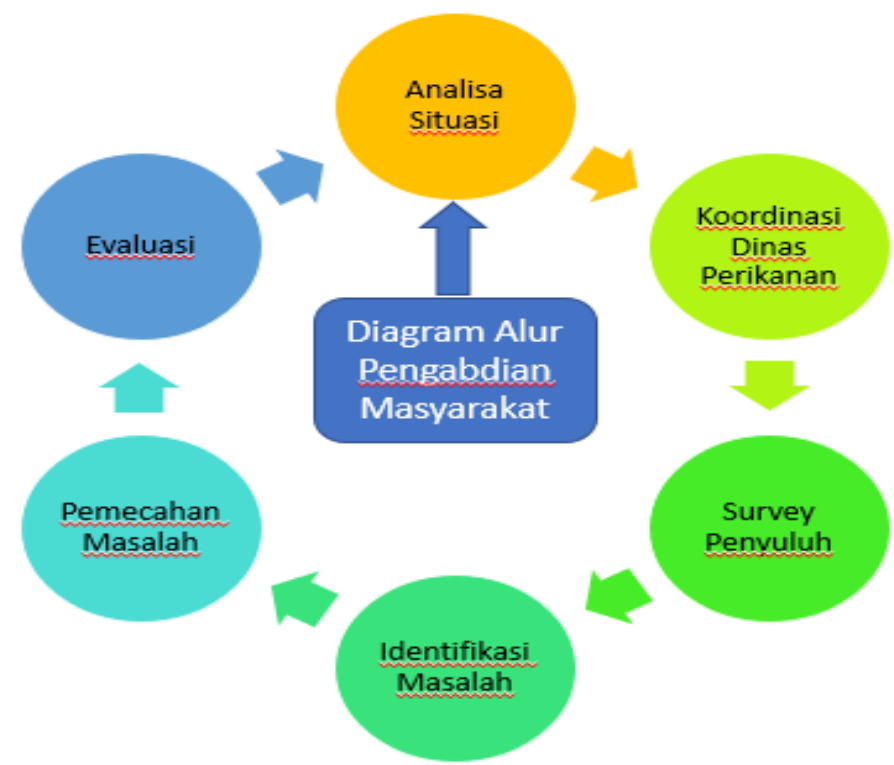

Gambar 1. Diagram Alur Pengabdian Masyarakat

Tahapan pengabdian masyarakat dimulai dengan adanya analisa situasi bahwa nelayan perikanan kepiting di ekosistem mangrove wilayah Kota Sorong masih belum sejahtera sesuai keadaan yang terlihat. Tim pengabdian masyarakat berkoordinasi dengan dinas 
perikanan untuk menyampaikan analisa situasi yang ada. Penyuluh melakukan survey pendahuluan untuk mendapatkan permasalahanpermasalahan yang ada. Masalah-masalah yang ada berdasarkan hasil survey dilakukan identifikasi masalah melalui Forum Group Discussion untuk mendapatkan gambaran permasalah yang lebih jelas dan mudah dicari solusinya. Permasalahan yang sudah diidentifikasi dilakukan pemecahan masalah melalui metode ceramah, simulasi, dan tanya jawab. Hasil kegiatan dievaluasi melalui wawancara untuk melihat ketercapaian kegiatan.

Materi pengabdian masyarakat sebagai berikut :

Tabel 1. Materi Pengabdian Masyarakat

\begin{tabular}{lll}
\hline No & Materi & Pemateri \\
\hline $\mathbf{1}$ & Progra m pengembangan usaha perikanan kepiting & Dinas Perikanan Kota Sorong \\
\hline $\mathbf{2}$ & $\begin{array}{l}\text { Proses memperoleh permodalan perbankan dan dukungan } \\
\text { terhadap nelayan }\end{array}$ & Bank BNICabang Sorong \\
\hline $\mathbf{3}$ & Analisa usaha kepiting bakau & Tim Pengabdi Politeknik \\
& & Kelautan dan Perikanan Sorong \\
\hline
\end{tabular}

Puncak pelaksanaan Pengabdian kepada Masyarakat dilaksanakan pada hari Sabtu, 26 September 2020, mulai pukul 09.00 s.d 16.00 WIT, dengan mengikutsertakan mitra sebanyak 30 orang (empat kelompok masyarakat perikanan kepiting). Kegiatan berlangsung dengan metode daring dan metode luring, metode daring adalah penyampaian materi oleh pemateri melalui aplikasi zoom cloud meeting sedangkan metode luring merupakan praktik ataupun simulasi serta tanya jawab yang dilaksanakan oleh tim pengabdian masyarakat bersama penyuluh perikanan yang langsung terjun ke wilayah mitra untuk lebih memahamkan materi yang diberikan oleh narasumber. Tim pengabdian masyarakat menggunakan laptop, infocus dan jaringan internet untuk menyambungkan komunikasi antara mitra dan narasumber, serta alat tulis untuk menyalin materi, menyiapkan tanya jawab serta simulasi lebih memahamkan mitra terhadap materi.

\section{HASIL DAN PEMBAHASAN}

Rangkaian kegiatan pengabdian masyarakat berupa Focus Group Discussion (FGD) berlangsung tanggal 03 September 2020 bertempat di Angkringan Kota Sorong. Peserta melakukan registrasi mengisi data biodata yang diperlukan untuk memperlancar kegiatan serta mempermudah dalam pelaksanaan kegiatan selanjutnya berupa pemberian materi dan pendampingan.

Kegiatan FGD dimaksudkan untuk memperoleh masukan-masukan mitra terkait kendala-kendala yang dihadapi oleh mitra dalam pelaksanaan pekerjaannya. Awal kegiatan pembahas/narasumber memberikan gambaran hubungan kerapatan mangrove dengan perikanan kepiting berkelanjutan, upaya-upaya yang dapat dilakukan oleh nelayan untuk dapat meningkatkan pendapatannya tanpa melakukan penangkapan yang merusak lingkungan.

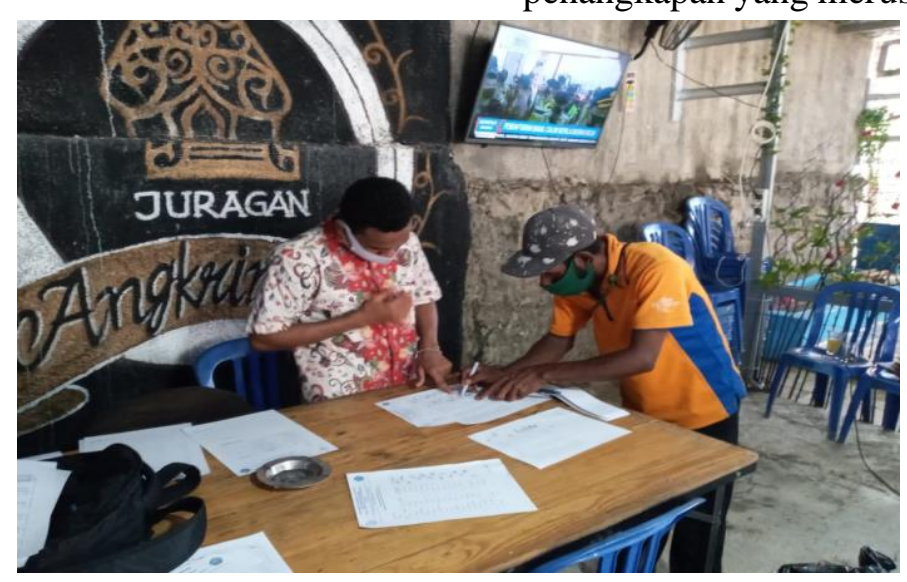

Gambar 2. Registrasi Peserta Focus Group Discussion 


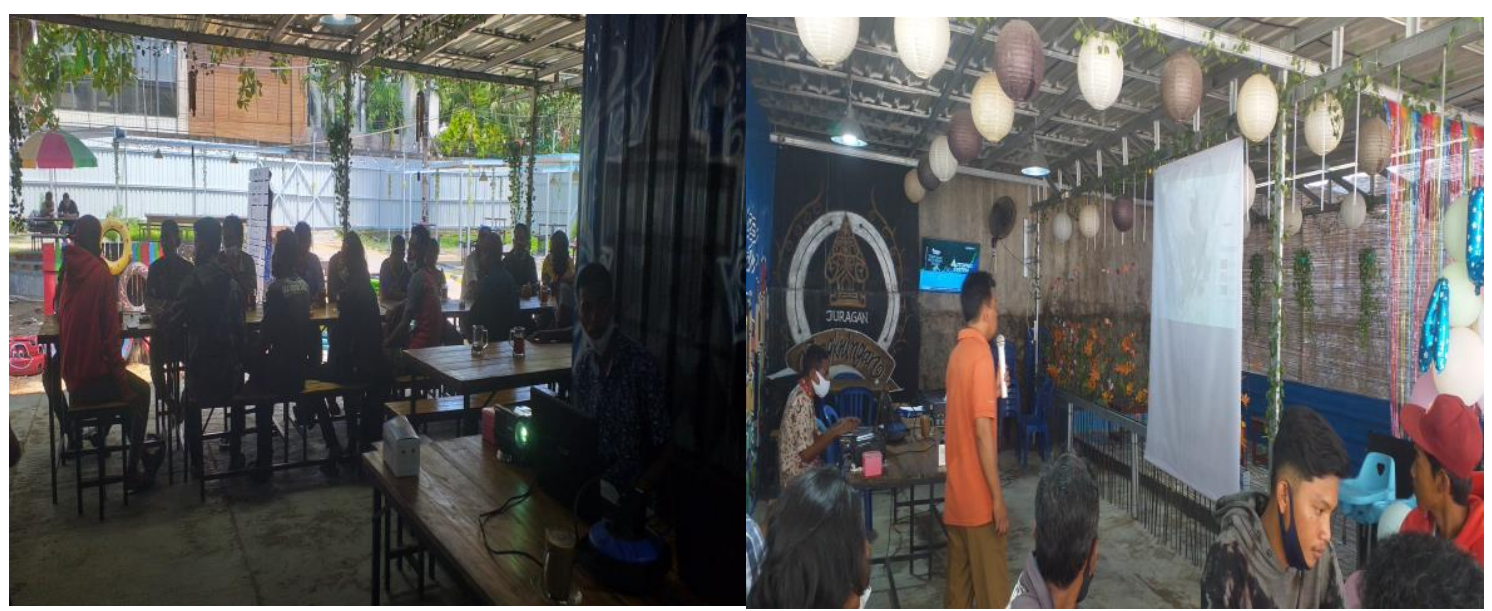

Gambar 3. Nelayan perikanan kepiting sebagai mitra mendengarkan paparan awal yang disampaikan oleh narasumber/pembahas

Narasumber usai paparan memantik peserta untuk melakukan tanya jawab, memberikan masukan dan berdiskusi. Arahan narasumber selanjutnya meminta masukan dari para peserta pengabdian masyarakat terkait jumlah hasil tangkap kepiting selama mitra menjadi nelayan perikanan kepiting, dinamika diskusi berjalan dengan baik, peserta pengabdian masyarakat dengan antusias memberikan pertanyaan-pertanyan kepada pembahas maupun memberikan masukan-masukan terkait topik yang dibahas. Beberapa masukan yang disarikan adalah :

1. Beberapa tahun yang lalu, sebelum tahun 2015, nelayan dengan mudah melakukan penangkapan kepiting karena saat itu belum banyak nelayan kepiting. Namun, akhir-akhir ini nelayan sulit mendapatkan banyak kepiting karena adanya banyak nelayan kepiting yang hadir.

2. Akhir-akhir ini rata rata pendapatan nelayan kepiting berkurang karena kepiting yang sudah ditangkap dijual dengan murah kepada pengepul.

3. Nelayan kesulitan untuk mendapatkan kepiting di wilayah sekitar tempat tinggal karena kekurangan peralatan untuk dapat menangkap ke wilayah yang padat kepiting yang letaknya memerlukan perahu.

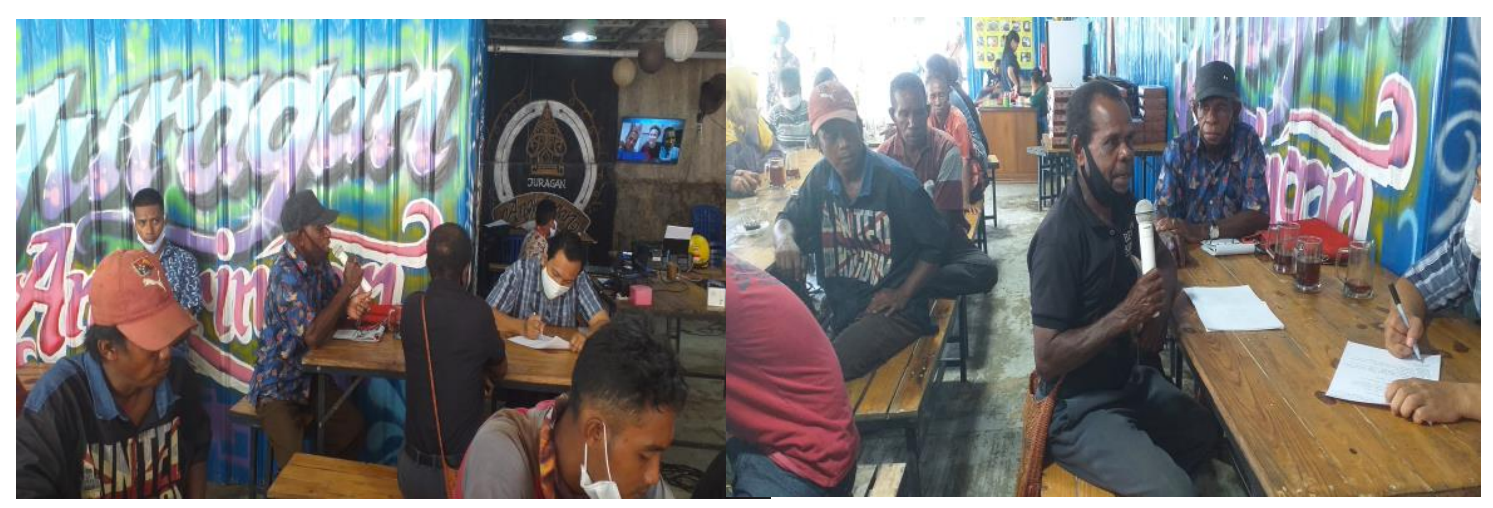

Gambar 4. Antusias mitra memberikan memberikan pertanyaan dan masukan pada diskusi

Program pengabdian masyarakat ini diharapkan berjalan efektif sesuai dengan tujuan yang telah ditetapkan. Keberhasilan program dicapai dengan cara menugaskan 2 pendamping di setiap kelompok mitra pada saat kegiatan. Penugasan pendamping juga disertai dengan memberikan 
lembar evaluasi awal berupa pertanyaan wawancara sebagai berikut:

Tabel 2. Hasil Pretest melalui wawancara dan pengamatan

\begin{tabular}{clcc}
\hline No. & \multicolumn{1}{c}{ Pertanyaan } & Ya & Tidak \\
\hline 1 & $\begin{array}{l}\text { Apakahpernah mendapat pendampingan Dinas } \\
\text { Perikanan }\end{array}$ & $100 \%$ & $0 \%$ \\
2 & $\begin{array}{l}\text { Apakahmemahami proses mendapatkan fasilita s } \\
\text { kredit perbankan }\end{array}$ & $10 \%$ & $90 \%$ \\
3 & Apakahmemahami a nalisa kelayakan usaha & $20 \%$ & $80 \%$ \\
\hline
\end{tabular}

Forum Group Discussion yang berlangsung selama satu hari tersebut mampu mengeksplorer informasi dan data permasalahanpermasalahan nelayan untuk dicarikan solusi pemecahannya. Hasil Focus Group Discussion disimpulkan bahwa nelayan memiliki keterbatasan modal serta kesulitan dalam mendapatkan akses permodalan untuk memenuhi peralatan yang dibutuhkan dalam melakukan penangkapan kepiting, begitu juga nelayan masih kurang dalam menganalisa usaha yang digelutinya sehingga dalam melaksanakan usahanya tidak memperoleh keuntungan yang optimal. Atas dasar permasalahan mitra tersebut disepakati untuk melakukan pengabdian masyarakat dengan mengundang Dinas Perikanan Kota Sorong dan pihak perbankan untuk memberikan fasilitasi permodalan. Politeknik KP Sorong juga memberikan materi sebagai bagian dari tugas fungsinya memberikan pemberdayaan masyarakat dengan materi analisa kelayakan usaha.

Pelaksanaan pengabdian masyarakat berlangsung pada Hari Sabtu, 26 September 2020 yang dimulai dengan pembukaan oleh Direktur Politeknik Kelautan dan Perikanan Sorong. Seusai pembukaan acara dilanjutkan dengan pemaparan materi oleh Dinas Perikanan Kota Sorong, Bank BNI Cabang Sorong, dan Politeknik KP Sorong.

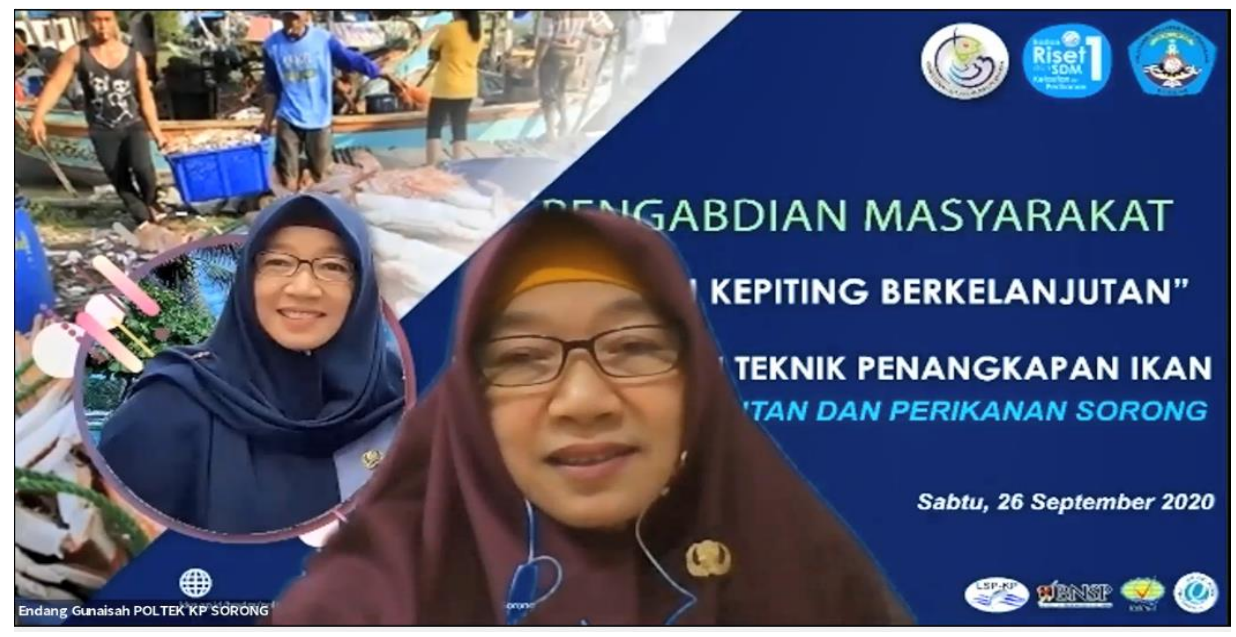

Gambar 5. Pembukaan Secara daring oleh Direktur Politeknik KP Sorong

Materi pertama dengan judul "Program Pengembangan Usaha Perikanan Kepiting" yang disampaikan oleh Dinas Perikanan Kota Sorong berupa informasi dan Langkah yang dilakukan oleh pemerintah Kota Sorong terhadap pengembangan usaha perikanan kepiting. Point utama yang disampaikan dari dinas perikanan adalah pelaku utama usaha perikanan kepiting didominasi oleh nelayan-nelayan tradisional dan potensi ekonomi yang dihasilkan oleh perikanan kepiting bakau sangat tinggi karena sejak tahun
2016 permintaan pasar kepiting bakau sudah melakukan pengiriman ke Makasar dan Jakarta, bahkan ke Luar Negeri seperti Hongkong dan Hongkong. Fasilitasi yang dilakukan oleh pemerintah Kota Sorong adalah melakukan koordinasi dengan pihak-pihak terkait sehingga kepiting di kirim pagi tiba di tujuan sore hari. Dinas perikanan juga mendorong melalui unit pelaksanan teknisnya memberikan kemudahan berinvestasi bagi usaha usaha kecil untuk 
melakukan pengolahan dan pemasaran kepiting bakau.

Materi kedua disampaikan oleh Bank BNI Cabang dengan judul "Upaya Perbankan Menfasilitasi dan Pendampingan Permodalan Nelayan Perikanan Kepiting Bakau melalui pembiayaan Kredit Usaha Rakyat", pemateri dalam paparannya menyatakan bahwa BNI sangat konsen mendampingi kredit usaha kecil termasuk kepada nelayan dengan berbagai skim pembiayaan. Skim yang ditawarkan oleh BNI merupakan skim modal kerja untuk membantu nelayan meningkatkan aktivitas usahanya. Upaya membantu nelayan kepiting BNI mengikuti skema bisnis nelayan kepiting, pembayaran pokok dan bunga dilakukan pada saat panen.

Kesempatan untuk berdiskusi pada materi kedua ini dimanfaatkan dengan baik oleh mitra pengabdian masyarakat. Pertanyaanpertanyaan mitra menyangkut kebutuhan modal kerja untuk meningkatkan aktivitas usaha dengan meningkatkan prasarana penangkapan, Pertanyaan-pertanyaan tersebut dijawab dengan penjelasan lebih detail untuk lebih memahamkan mitra dalam proses pembiayaan.

Materi ketiga disampaikan dengan judul “Analisa Kelayakan Usaha Perikanan Kepiting”, materi dibawakan oleh tim dosen Politeknik KP Sorong. Materi ini diberikan bagi usaha yang sudah berjalan maupun untuk perencanaan usaha. Tujuan pemahaman analisa kelayakan usaha untuk memudahkan perencanaan, pelaksanaan, pengawasan, dan pengendalian usaha yang akan dijalankan maupun yang sedang berjalan (Pratiwi et al., 2019). Pemateri memberikan gambaran analisa usaha berdasarkan data-data usaha yang diberikan oleh nelayan kepiting saat kunjungan lapang ke mitra. Paparan juga sekaligus mengevaluasi usaha perikanan yang sudah dijalankan menjadi bahan pertimbangan untuk dijalankan, dievaluasi Kembali atau dihentikan usaha tersebut untuk menghindari kerugian yang lebih banyak. Pemateri memberikan konsep konsep operasional penangkapan kepiting per trip dengan one day fishing. Nelayan diajarkan metode analisis dengan membedakan biaya tetap dan biaya operasional hingga menentukan keuntungan, analisa yang kedua yang dipaparkan adalah analisa Benefit Cost Ratio untuk mengetahui tingkat efisiensi/kelayakan usaha.

Khusus materi ketiga ini juga dilakukan simulasi analisa usaha dilapangan yang dilakukan oleh penyuluh dan tim pengabdian sekaligus konsultasi pengembangan usaha. Hasil analisa usaha yang diberikan oleh penyuluh dan tim pengabdian masyarakat pada umumnya usaha yang dilakukan oleh nelayan perikanan kepiting memiliki tingkat keberhasilan yang tinggi dan keuntungan yang menjanjikan. Namun, pola hidup konsumif nelayan dan tidak berorientasi kepada masa depanyang mengakibatkan nelayan sulit untuk hidup sejahtera (Siregar, 2016). Pengabdi di lapangan juga memberikan masukan untuk mengurangi pola hidup konsumtif.

Dipenghujung kegiatan dilakukan evalusi hasil kegiatan oleh tim di lapangan dengan hasil data tabel 3 .

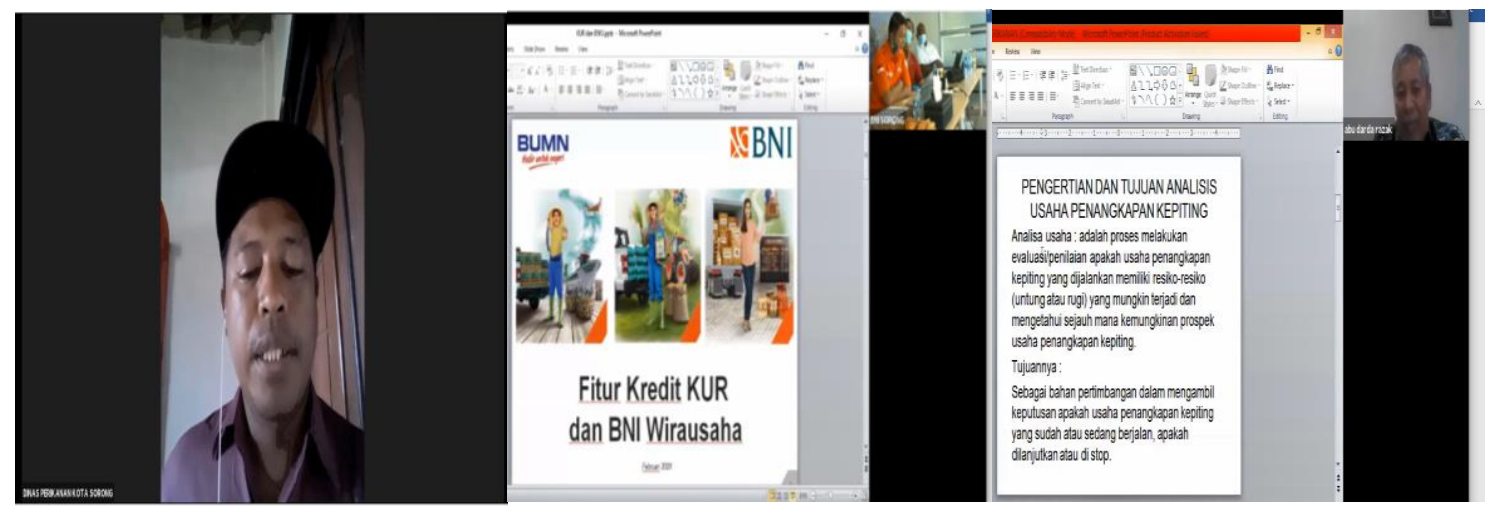

Gambar 6. Peny ampaian Materi Secara Daring 
Tabel 3. Hasil Posttest melalui wawancara dan pengamatan

\begin{tabular}{clcc}
\hline No. & \multicolumn{1}{c}{ Pertanyaan } & Ya & Tidak \\
\hline 1 & $\begin{array}{l}\text { Apakah pernah mendapat pendampingan Dinas } \\
\text { Perikanan }\end{array}$ & $100 \%$ & $0 \%$ \\
2 & $\begin{array}{l}\text { Apakahmemahami proses mendapatkan fasilitas } \\
\text { kredit perbankan }\end{array}$ & $80 \%$ & $20 \%$ \\
3 & Apakahmemahami analisa kelayakanusaha & $70 \%$ & $30 \%$ \\
\hline
\end{tabular}

\section{SIMPULAN DAN SARAN}

Kekayaan sumber daya alam bahari yang bernilai ekonomis tinggi harusnya bisa menjadi sumber peningkatan kesejahteraan masyarakat pesisir yang mengantungkan hidupnya pada alam. Namun, nelayan terkendala akses pemodalan untuk dapat meningkatkan prasarana penangkapan yang dapat meningkatkan hasil tangkapan. Nelayan juga tidak memiliki pengetahuan analisa kelayakan usaha untuk membekali perencanaan usaha yang dapat memprediksi tingkat keberhasilan usaha.

Pengabdian masyarakat menjembatani adanya kebutuhan mitra untuk memahami proses mendapatkan fasilitas permodalan serta pengetahuan analisa kelayakan usaha sebagai bekal dalam melaksanakan usahanya. Tim pengabdi Politeknik KP Sorong bersama Dinas Perikanan Kota Sorong dan Bank BNI Cabang Sorong mensolusikan permasalahan tersebut dengan memberikan program pengembangan nelayan, pemahaman proses mendapatkan permodalan, dan analisa kelayakan usaha. Selain itu juga memberi masukan untuk mengurangi pola hidup konsumtif.

Pemahaman mitra terhadap materi yang diberikan dinilai dengan menggunakan wawancara oleh tim pengabdi yang terjung langsung mendampingi. Hasil wawancara terjadi peningkatan pemahaman proses mendapatkan kredit menjadi $80 \%$ dan pemahaman analisa kelayakan usaha menjadi $70 \%$.

Saran yang dapat dikemukakan dari hasil pengabdian masyarakat ini sebagai berikut :

1. Nelayan perlu mendapatkan pendampingan secara reguler terlebih dalam mendapatkan fasilitas permodalan dan analisa kelayakan usaha;

2. Pembentukan kelompok nelayan dalam bentuk Kelompok Usaha Bersama dapat menjadi solusi dalam mendapatkan permodalan.

3. Akses pasar hasil tangkap juga harus dibantu mengingat harga penjualan hasil tangkap juga berfluktuasi.

\section{UCAPAN TERIMAKASIH}

Ucapan terimakasih disampaikan kepada Direktur Politeknik Kelautan dan Perikanan Sorong atas pendanaan pengabdian masyarakat ini sehingga dapat berjalan sesuai dengan tujuan, kepala Pusat Pengabdian kepada Masyarakat atas saran-saran dalam pelaksanaan pengabdian kepada masyarakat. Kepala Dinas Perikanan Kota Sorong atas dukungan kolaborasi program pengabdian masyarakat, Bank BNI Cabang Sorong yang memberikan materi pengabdian kepada masyarakat bagi mitra nelayan kepiting bakau.

\section{DAFTAR PUSTAKA}

Anwar, Z. W. (2019). Miskin Di Laut Yang Kaya: Nelayan Indonesia Dan Kemiskinan. 1(4), 52-60.

Econusa. (2020). Laporan Pelaksanaan Ekspedisi Mangrove Papua Barat.

Makinggung, J. P. T., \& Winokan, J. R. (2017). Analisis Aksesibilitas Modal Kerja dan Investasi bagi Nelayan Tradisional di Kota Manado. Prosiding Sentrinov (Seminar Nasional Terapan Riset Inovatif), 3(1), EB137-EB148.

O. Nyumba, T., Wilson, K., Derrick, C. J., \& Mukherjee, N. (2018). The use of focus group discussion methodology: Insights from two decades of application in conservation. Methods in Ecology and Evolution, 9(1), 20-32.

Patra, A. D. A., \& Patra, I. K. (2018). Pemberdayaan Manajemen Usaha Kelompok Pembudidaya Tambak di Desa Manurunng Kecamatan Malili Kabupaten Luwu Timur. RESONA: Jurnal Ilmiah Pengabdian Masyarakat, 2(2).

Pratiwi, S. R., Prihartanto, E., Rahmawati, M., \& 
Usman, S. (2019). Pelatihan Penyusunan Laporan Studi Kelayakan Kepada Masyarakat Bisnis Pada UMKM. CARADDE: Jurnal Pengabdian Kepada Masyarakat, 1(2), 148-154.

Siti, N. S. S. (2016). Kesadaran Masyarakat Nelayan terhadap Pendidikan Anak. JPPUMA: Jurnal Ilmu Pemerintahan Dan
Sosial Politik UMA (Journal of Governance and Political Social UMA), 4(1), 1-10.

Tristiarto, Y., Kusmana, A., \& Siswantini, T. (2017). Pelatihan dan Pendampingan Penyusunan Proposal Pengajuan Kredit Bank Bagi Kelompok Usaha Perikanan di Wilayah Kelurahan Rangkapan Jaya Baru. Bina Widya, 26(2), 95-100. 